\title{
The Housing And Economic Recovery Act Of 2008
}

Steven L. Kroleski, B.A., J.D., Iona College, USA

Patrick J. Reville, B.B.A., J.D., Iona College, USA

George A. Mangiero, B.A., M.B.A., Ph.D., Iona College, USA

\begin{abstract}
The 2008 economic crisis world-wide was caused by many factors. However, of the most blatant contributors in the U.S. were the failure of sub-prime mortgages and the government's failure to properly regulate the banking loan industry. This triggered the passage of the Housing and Economic Recovery Act of 2008, which was enacted on July 30, 2008. This Act, in the collective opinions of the authors, is a little too little and a little too late to actually remedy the massive harm caused by these types of loans and the abuses in the home loan industry.
\end{abstract}

Keywords: refundable tax credit, sub-prime mortgage, seller's concessions.

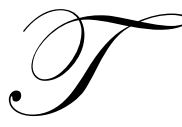

his recent law, enacted on July 30, 2008 (1), seeks to alleviate the sub-prime mortgage crisis by, among other things, the government guaranteeing up to $\$ 300$ billion in new 30 year fixed rate mortgages.(2)

One of the more heralded aspects of this legislation was the provision of a First-Time Home Buyer Tax Credit.(3) The objective of this tax credit is to give the faltering housing market a quick booster shot in the arm by attempting to put a stop to falling housing values, while at the same time giving people now living in rental housing units an incentive to acquire the American Dream: ownership of their own homes.

Among the highlights of the First-Time Homebuyer provisions are:

a refundable tax credit up to the amount of $\$ 7,500.00$ (4), which is available only to first-time home buyers as defined by the statute (5) (This tax credit in reality is not a credit, but instead an interest-free loan that must be paid back over 15 years. (6));

(ii) this tax credit is only available for homes that were purchased on or after April 9, 2008 and before July 1, 2009 (7); and,

(iii) this tax credit is available for single taxpayers with an income of less than $\$ 75,000.00$ a year, and for married couples with a combined income of up to $\$ 150,000.00$ per year (8).

The Act establishes and grants powers to the Federal Housing Finance Agency (FHFA) to operate both Fannie Mae and Freddie Mac (9).

As listed above, the Act's Tax Credit is a refundable credit (10). What does this mean? A credit is traditionally treated as a direct lessening of a tax liability (11). That is, if a person owed $\$ 4,500.00$ on his or her income tax return, and that person was entitled to take a $\$ 2,000.00$ tax credit, then the actual tax liability would be reduced to $\$ 2,500.00$.

Using the above example, what if the person instead only owed $\$ 1,000.00$ on his or her taxes? That person, although entitled to a credit of $\$ 2,000.00$, would only be able to offset the taxes due, and in a sense, not be able to use the additional $\$ 1,000.00$ credit to his or her advantage. 
The new Act provides for a refundable tax credit. So now, the taxpayer that owes $\$ 1,000.00$, and is entitled to a refundable tax credit of $\$ 2,000.00$, would not only wipe out his or her tax liability, but would then also be entitled to a refund check of $\$ 1,000.00$ for the unused portion of the refundable tax credit.

Another nice aspect of this tax credit is, that if you purchased your home in 2008, you have the option of electing whether you take the credit on your 2008 or 2009 tax return. (12) If you purchase a home in 2009, the same option applies, but in that case, if you already filed your 2008 tax return, you would have to file an amended return for that 2008 tax year.

As earlier set forth, there are caps on the amount of income that you can earn to qualify for the loan. However, taxpayers that exceed these levels could still receive the benefit of the credit, but the amount would be reduced by the amount of money that you earn over the caps. This reduction in the credit is not necessarily a dollar for dollar loss to the taxpayer, but does become phased out and totally unavailable to the single taxpayer that earns over $\$ 95,000.00$ and for married taxpayers, the ceiling amount is $\$ 170,000.00$ (13).

"Income" is referred to as Adjusted Gross Income for the purposes of qualifying for the credit, with certain adjustments as concerns foreign income, foreign housing deductions, student loan interest deductions, I.R.A. contribution deductions and deductions for higher education costs. This is known in the statute as Modified Adjusted Gross Income (MAGI). (14)

Adjusted Gross Income means that the taxpayer is entitled to deduct from his or her gross earnings items that are allowed by the Internal Revenue Service (15). These adjustments are found on the lower portion of an individual/personal the 1040 tax return form, on the first page. Typical items that are permitted are alimony paid, I.R.A. contributions, etc. Close attention to detail is required for the computation of income to qualify under this law, so the taxpayer would be wise to seek professional advice in the preparation of his or her tax return.

Now the bad news. This credit must be paid back. So, although it is packaged as a free give-away by the government, there is no such thing as a free lunch, or in this case, a free credit. On the good side, it is an interest free loan payable over a fifteen year span, after an initial two year grace period (16). What if the taxpayer should sell his or her home before the credit is paid back? Then, it must be paid upon the sale of the residence (17). What if upon the sale, there are not sufficient proceeds to pay back the credit? Then in that case, the obligation to pay back the credit would be forgiven (18). This forgiving of the debt could be another way that dishonest borrowers cheat the government. How? By a reduction of the purchase price on the contract of sale, so that it would now appear that there will not be enough net proceeds to pay back the credit. The purchaser and seller could have a side deal for the difference by either paying a portion of the house cost in cash, or by designating these additional monies as the cost for purchasing personal property left behind by the seller. For example, a dining room set, children's swing set, etc. These monies would then not be considered proceeds from the sale of the home. As an additional note, death of the taxpayer would also result in forgiveness of this payback. (19)

Another provision of the new law is that for 2008, taxpayers who elect not to itemize their deductions, yet pay real property taxes, will be entitled to receive a $\$ 500.00$ additional standard deduction on their return $(\$ 1,000.00$ for joint returns) (20). The intent of the legislators was apparently to assist taxpayers who paid off their mortgages and no longer have a sizeable home mortgage interest deduction to itemize.

To qualify for yet another provision of the Act (regarding re-financing), which began on October 1, 2008 and is to run until September 30, 2011, the borrower must:

1. have an outstanding mortgage on their principal residence (no vacation or second homes);

2. attest that he or she has not "intentionally" defaulted on the mortgage; and,

3. affirm that he or she did not obtain the existing loan fraudulently, and in addition, has never been convicted of a fraud-related crime. (21) 
The act was also created to cut-off additional foreclosures by having the Federal Housing Administration guarantee up to $\$ 300$ billion in refinanced mortgages on condition that the new lenders accept partial payments. (22) In this way, the borrowers' new outstanding loan payments will be more affordable.

The new law increases coverage to $115 \%$ of an area's median home price, to a maximum of $\$ 625,000.00$, with a minimum down payment downpayment of 3.5\% of the purchase price (being increased from 3\%). (23) This might appear to be a paradox, whereby you can potentially borrow more, but your downpayment must be higher. The end result does not appear to be a "tightening" of standards on the requirements for obtaining a loan. The additional $0.5 \%$ does not amount to much, considering the borrower could qualify for the $\$ 7,500.00$ credit. In addition, another gimmick used by borrowers for their down payments, is that the monies they are using are a gift from a relative, so that they simply get their relative to sign a "gift letter". This trick is used because the borrower can not show that these funds are coming out of one of his or her accounts. These monies could be gifts, but they also could be family loans. Realistically, should person making $\$ 75,000.00$ annually (150,000.00 jointly), qualify for a $96.5 \%$ loan on a $\$ 625.000 .00$ purchase? Should the Federal government be guaranteeing or insuring these types of loans? You be the judge. These funds are not going to alleviate the dismal real estate market, but are destined for future loan failures ahead.

Freddie Mac and Fannie Mae collapsed and had to be taken over by the Federal government. The lack of management skills of these entities was unbelievable. Franklin Raines at Fannie Mae earned mega-millions in compensation and bonuses, and left his position under a cloud of accounting fraud. He recently agreed to pay restitution/fines in the amount of over $\$ 24$ million, and additionally forfeit stock options valued at over $\$ 15$ million.(24) Add to that the blind "oversight" of Senator Chris Todd's (Senate) and Representative Barney Frank's (Congressional) committees, and others, who were at best "asleep at the switch"(25), and you need to ask the question: "Are these folks going to oversee the new programs?" Again, you supply the answer.

No discussion of attempts, governmental or otherwise, to calm the stormy seas of the housing and mortgage markets would be complete without a brief examination of the sub-prime mortgage fiasco, which greatly contributed to the economic meltdown of 2008. But where is the blame to be placed? Wall Street? the banking industry? Congress? The simple answer is that there are many parties who should foot the blame.

Congress apparently was unwilling or unable to place restrictions on or regulate issuance of such loans. (26) The politicians had good intentions on assisting lower income people into home ownership, but foresight was lacking. Without any restrictions of consequence being in place, the American Dream has become a nightmare for many who ended up in foreclosure and/or personal bankruptcy. Not many speak out against the borrowers themselves as being responsible, because those poor naïve souls relied on the constant flow of infomercials that promised them wealth in the real estate market. "Buy real estate with no money down, no closing costs, no attorneys fees, etc." Unscrupulous real estate and mortgage brokers were also responsible, as were attorneys.

One of the "tricks" utilized by brokers and borrowers to fund undercapitalized purchases was a devise known as the "seller's concession". This practice has recently resulted in Attorney General opinion letters in both New York and New Jersey to the effect that allowing such a practice could be unethical, unless a real concession, and if that be the case, that this concession should be disclosed to all potential ultimate purchasers of the loan, to wit: make note of it in the recorded documents.

A seller's concession is when a seller, by pre-arrangement, gives money or credit back to the purchaser at closing, purportedly for repairs, closing costs, etc. Although a legal practice, it became a totally abusive way for the purchaser to inflate the purchase price, and in so doing, increase the amount of money he or she could borrow.

EXAMPLE: A house was to be sold for $\$ 250,000.00$ and financed at $95 \%$ (or the amount of $\$ 237,500.00$ ). In a straight deal, the borrower would need about $\$ 20,000.00$ to close the purchase (a down payment of $\$ 12,500.00$ and closing costs of about $\$ 7,500.00$ ). As this would leave many purchasers without money for a rainy day, the seller and buyer would arrange to artificially increase the purchase price by $\$ 15,000.00$ (or to the amount of $\$ 265,000.00$ ). The buyer would then put in the contract that he or she was to receive a seller's concession of $\$ 15,000.00$ at the closing of title to be used for closing costs and/or repairs. This money was never intended to be given to the 
purchasers, but now upon making the purchase price the sum of $\$ 265,000.00$, the borrower could borrow $95 \%$, or the sum of $\$ 251,750.00$ (more money than the cost of the house, and unfortunately for the banks, more money than the house was actually worth). This practice naturally had the complicity of real estate appraisers who went along with the new increased contract price. Many bankers, real estate brokers, mortgage brokers, appraisers and borrowers on the intake level were all to blame. The cash and carry away scheme at closings became too much temptation for many. If the mortgage did not get paid, the bank ended up being owed more than the actual value of the house, and further, all house values came tumbling down to boot. The bottom line is that with each foreclosure, the banks were taking on tremendous losses. The inevitable bank failures were soon to follow. (27)

For more expensive properties, another trick was employed. When the purchaser was buying his or her home, he or she would not only obtain a first mortgage, but at the same time take out a home equity loan.

EXAMPLE: The purchaser is buying a house for the cost of $\$ 650,000.00$. With $90 \%$ financing, the loan would be at $\$ 585,000.00$. If your loan exceeds the amount of $\$ 417,000.00$, it is considered a jumbo loan, which means that you would pay a higher interest rate. Also, if you borrow more than $80 \%$ of the value of the home, you would be compelled to pay private mortgage insurance (PMI) at possibly $\$ 250.00$ more a month. Enter the creative mortgage broker with a money-saving solution. The purchaser would borrow $\$ 417,000.00$ as the first mortgage, which is less than $80 \%$, so that the P.M.I. is not needed. Further, since the loan was no longer a jumbo loan, the interest would be at a lower rate. The balance of the loan needed, the sum of $\$ 168,000.00$, would be secured by virtue of a home equity loan. At the outset, the loans could be quite manageable. However, if they were adjustable rate mortgages (which they commonly were), and the interest rates increased, the borrower could find himself/herself in deep financial trouble.

\section{CONCLUSION}

The Housing and Economic Recovery Act of 2008, while well intended, seems to be positioned for failure. The past lack of regulation of and sanctions for the practices set forth above will probably persist, and will make this new money a free-for-all for the greedy. In addition, the Act requires the government to spend a certain amount of money within a relatively short period of time; that alone, it is submitted, is a recipe for corruption. Hopefully the real estate market will stabilize, but unfortunately, we predict more foreclosures and decreased home values unless the Bankruptcy Act is also amended to specifically address these problems.

\section{AUTHOR INFORMATION}

Steven L. Kroleski, Esq. is a graduate of St. John's University School Of Law (J.D., 1975), and began his legal career in New York City with the law firm of Milbanck, Tweed, Hadley and McCloy. He became an Assistant Professor at Iona College in 1981, and continues in that capacity to date. He also has a private law practice in Westchester County, New York, where he specializes in Business, Trusts and Estates, Real Estate and Matrimonial Law.

Patrick J. Reville, Esq. earned a B.B.A. degree in Accounting from Iona College, New Rochelle, New York, in 1965, and the Juris Doctor degree from the Fordham University School of Law in 1968. He joined the Iona College faculty in 1975, and is presently an Associate Professor of Business Law there. Attorney Reville has practiced law and accounting in Westchester County, New York, for forty (40) years, and presently devotes his practice time to Criminal Law, Small Businesses, Real Estate and Estates.

George A. Mangiero, Ph.D. is a Associate Professor of Finance and Economics at Iona College in New Rochelle, New York. Dr. Mangiero's graduate degrees include an MS in Electrical Engineering from Rensselaer Polytechnic Institute, an MBA in Finance from St. John's University, and an M.Phil and Ph.D. in Finance from New York University. His research interests are primarily in the areas of Portfolio Management, Financial Futures, Options and Swaps, and Corporate Finance. He resides with his wife in Connecticut. 


\section{ENDNOTES}

1. The Short Title of this Act is the "Housing and Economic Recovery Act of 2008." It is also known as H.R. 3221, which is a compilation of Acts which revamp the financial structure in many areas of the regulatory field, including taxation. In the notes that follow, it will be cited as "The Act", with appropriate Section reference(s).

2. $\quad$ The Act, Sec. 1401 et seq., entitled the "HOPE for Homeowners Act of 2008."

3. The Act, Sec. 3011. First-Time Homebuyer Tax Credit, which replaces Section 36 of Title 26 of the U.S. Code (encompassing The Internal Revenue Code).

4. The Act, Sec. 3011, 26 USCS Section 36(b)(1).

5. $\quad 26$ U.S.C.S. Sec. 36(a). First-Time Homebuyer defined in Sec. 36(c)(1).

6. $\quad$ See id. Sec. 36(f)(7).

7. $\quad$ See id. Sec. 36(h).

8. $\quad$ See id. Sec. 36(b)(2).

9. The Act, Sec. 1101 (which amends the Federal Housing Enterprises Financial Safety and Soundness Act of 1992 (12 U.S.C. 4501, et seq) by striking Sec. 1311 and 1312 and inserting a new Sec. 1311).

10. J. K. Lasser, Your Income Tax 2008783 (2007).

11. Id.. at 781 .

12. 26 U.S.C.S. Sec. $36(\mathrm{~g})$.

13. See id. Sec. 36(b)(2).

14. Id..

15. Lasser, at 779.

16. 26 U.S.C.S. Sec. 36(f)(7).

17. See id. Sec. 36(f)(2).

18. See id. Sec. 36(f)(3).

19. See id. Sec. 36(f)(4).

20. The Act, Sec. 3012. Additional Standard Deduction For Real Property Taxes For Nonitemizers.

21. The Act, Sec. 1401 et seq., entitled the "HOPE for Homeowners Act of 2008."

22. Id.

23. The Act, Sec. 2101 et seq., entitled the "FHA Modernization Act of 2008."

24. Cindy Skrzycki, A Gutsy David takes On Goliath, Washington Post, Dec. 28, 2004, at E01; Kathleen Day and Terence O'Hara, False Signatures Aided Fannie Mae Bonuses, Falcon Say, Washington Post, Apr. 7, 2007, at E01; and, Scandal to Cost Ex-Fannie Mae Officers Millions, The Associated Press, Apr. 19, 2008.

25. Editorial, What They Said About Fran and Fred, Wall St. J., Oct. 2, 2008, wherein Reps. Frank (D., Mass), Maxine Waters (D., Calif.) and Gregory Meeks (D., N.Y.), along with Senators Dodd (D., Conn.), Thomas Carper (D., Del.), Richard Shelby (D., Ala.), Robert Bennett (R., Utah) Chuck Hagel (R., Neb.) and Charles Schumer (D., N.Y.) are quoted on the record at various House Financial Services and Senate Banking Committee meetings in 2003, 2004, 2005 and 2006 as taking a basic hands off "What, Me Worry?" approach to Fannie Mae and Freddie Mae operations and/or praising those institutions' successes, not excesses.

26. The F.D.I.C. reports on its official web-site that three (3) U.S. banks failed in 2007, while the number rose in 2008 to twenty-two (22) through its report dated 11/21/08 


\section{NOTES}

